\title{
Strengthening the capacity of village government in the implementation of village fund policy at Maros regency of South Sulawesi province
}

\author{
Mohamad Thahir Haning; Mashuri H. Tahili \\ Faculty of Social and Political Science, Hasanuddin University, Indonesia; \\ Faculty of Social and Political Science, Muhammadiyah University of Luwuk Banggai, \\ Indonesia \\ thahir.haning@gmail.com; mashuritahili1971@gmail.com
}

\begin{abstract}
This study aimed at to analyze and describe the strengthening of the village government capacity in the village fund policy implementation. The model of strengthening the village government capacity is proposed in order to revitalize village development, make community institutions more representative and accountable, and improve state-society relations. The developed model stemmed from strategic thinking, empowerment, social capital, and the community participation. The data was taken from informants which have been selected purposively, and other data were gained from secondary data analysis such as; bulletin, journal, and mass media, which have relevance to the research focus. The data collection techniques used are observation, interview, and documentation review. The data were analyzed through interactive analysis model consisting of four stages; data collection, reduction, presentation, and conclusion. The result shows that the strengthening the capacity of village government in the implementation of village fund-policy implementation at Maros Regency was not optimal. It can be proved that the four dimensions such as; strategic thinking, empowerment, social capital, and the community participation are not optimally achieved. The main objectives of village fund policy to strengthen the capacity of village government and the community of Maros Regency has not been implemented effectively.
\end{abstract}

Keywords: capacity strengthening, village government, policy implementation, village fund

\section{Introduction}

Nowadays, Indonesia village government has been struggling with limited resources and capacity to meet their growing responsibilities in providing their society with services related to the infrastructure, empowering, education, public health, economic development, and enabling social participation to flourish in their communities. In the effort to help village government to respond to their challenges. Based on the Village Rural Development and Transmigration Ministerial Regulation No. 5 of 2015, it is stated that the fund aims to improve the welfare of rural communities and the quality of human life, as well as poverty reduction, through: (1) the fulfillment of basic needs; (2) the development of rural infrastructure; (3) the potential development of local economies; and (4) the use of natural resources in an environmentally sustainable manner. The Village Law itself does not provide an adequate enough basis for 
regulating proper village financial management. Some believe that the initiative is all about the distribution of money with no clear plan for its proper management (East Asia Forum 2015).

In implementing the village fund policy, some problems should be faced by Indonesian government at Maros Regency of South Sulawesi Province. The early observation showed that the aims of village fund policy has not been achieved effectively. There were some parameters such as; developing infrastructure, empowering community, society economic development, and community participations which were so hard to be developed effectively. This problems might be occurred because the village government has not been fully capacity to implement the village fund policy.

There are some empirical researchers conducted the study about the impacts of the implementation of village fund policy in Indonesia, such as; Asni et al (2013) conducted the research to investigate the process of implementation of the program of fund allocation for the village which is divided into four main lines: the processing of planning of village funds, the process of the allocation management of village fund, the process of administering the village fund program, the process of reporting program. They found that the implementation of fund allocation program in the village of Rawang Air Putih and the village of Teluk Merbau played an important role in the efforts to make the implementation more efficient and effective such as; reducing the occurrence of asymmetric information, planning is lacking according to the needs of the village, the occurrence of irregularities as well as other problems that would make the implementation of village fund policy becomes less efficient and effective.

Boonperm et al (2012) found that based mainly on a custom-built survey of more than 3,000 Village Funds conducted in 2010, this paper evaluates the performance of Village Funds, which it argues are best modeled as altruistic, and do not appear to be subject to elite capture. There were two sides of the capacity building or capacity development that must be taken into account by the village government to manage the village fund policy. The capacity building is the process through which individuals, organizations, and societies obtain, strengthen, and maintain the capabilities to set and achieve their own development objectives over time" (UNDP, 2008). It means the program of village fund needs to focus on the process of developing the capacity of village head and community and strengthen the social capital. According to The World Bank, Africa Region stated that "The proven ability of key actors in a society to achieve socio-economic goals on their own. This is demonstrated through the functional presence of a combination of most of the following factors: viable institutions and respective organizations; commitment and vision of leadership; financial and material resources; skilled human resources" (World Bank, 2006).

Horton, et al (2003) argued that the capacity development consists of the main terms such as; (a) linking to organizations' mission, strategy, and values, (b) clear purpose and intent, (c) clear division of roles and responsibilities, (d) principled negotiation and joint decision-making, (e) openness to learning and change, (f) continuity and persistence, and (g) flexibility. In this article is purposed to analyze, describe, and interpret the strengthening the capacity of village government in the implementation of village fund policy, we used theory of capacity building (UNDP 2009) which elaborates that capacity building consists of five programs such as: engaging stakeholders 
on capacity development, assessing capacity assets and needs, formulating capacity development program, implementing a capacity development response, evaluating capacity development. The new capacity building jargon signifies an entrenchment of notions of what constitutes capacity, which defines capacity and what constitutes their relationships between the dominant culture capacity builders and those identified as capacity deficient. Definitions of capacity development vary depending on the sector or particular program focus, but a common definition is "ability of individuals, organizations or systems to perform appropriate functions effectively, efficiently and sustainability.

Based on the theory above, we classify the model of strengthening the capacity of village government into four dimensions included: strategy of thinking, empowerment, social capital, and community participation. The strategy of thinking relates to the capacity of village government to formulate and plan program which is suitable with the village community basic needs, the empowerment relates to the knowledge and skill of government to develop and allocate the village fund budgeting to give the education and training, socialization, and give the support to the community basic skill. The social capital is correlated with the development of social knowledge and economic development, and culture. While, community participation is the wish of people or community to support the implementation of village fund policy. Based on the above explanation, so that the problem statement of this research can be formulated as follows:

1. How does the the capacity of village government in the implementation of village fund policy at Maros Regency?

2. How is the effectiveness of village fund policy implementation at Maros Regency?

\section{Methods}

This research was conducted in the Maros Regency, South Sulawesi Province. Based on the secondary data analysis, it was revealed that Maros Regency Area 1619.11 kilometers square consisting of 14 (fourteen) districts in charge of 80 Villages, Maros Regency is a region directly adjacent to the capital of South Sulawesi Province, in this case is the City of Makassar with the distance between the two cities is around 30 kilometers square and simultaneously integrated in the development of the Mamminasata Metropolitan Area. Maros Regency is located has an important role in the development of Makassar City as a crossing area as well as the gate to the northern region of Mamminasata which in itself provides a very big opportunity for development in Maros regency with an area of 1619.12 kilometers square and is divided into 14 district regions. This study used a qualitative approach with exploratory survey. The informants of this research consisted of; district head (Camat), village Head (Kepala Desa), Village Secretary, The Village Community Empowerment Agency (LPMD), The Village Deliberative Body (BPD) which have been selected purposively based on their knowledge and experience about the implementation of village fund policy at Maros Regency.

The data was taken from informants which have been selected purposively, and other data were gained from secondary data analysis such as; bulletin, journal, and mass media, which have relevance to the research focus. The data collection techniques used are observation, interview, 
and documentation review. The data were analyzed through interactive analysis model consisting of four stages; data collection, reduction, presentation, and conclusion.

\section{Result and discussion}

\section{The Village Government Capacity in the Village Fund Policy Implementation}

Based on Statistic Center Agency Report of South Sulawesi Province, twenty-one regencies have the village fund allocation by total IDR 1.274.386.920.000. Each villages has equal amount of village funding IDR 565.640.000, and the total village fund is IDR 11.878.440.000. It is interesting to analyze that the distribution of village fund is based on the total villages for each regency. It means that each regency has differences in village fund allocation, and Maros Regency gets IDR 251.200.000, based on the total village is only 80 one. The Government Act No. 43 year 2014, Article 48 point (c) states that the Village Head shall submit a written statement of the administration to the Village Deliberation Agency (BPD) at the end of each fiscal year. Through the analysis of interview and in-depth interview, the theme of "strengthening the capacity of village government" might emerge. Among the data, there were references from both the village heads at Maros regency which have been selected purposively.

\section{Strategy of Village Government}

In this dimension, we have gathered some data to prove how the village government used their strategy in the implementation the village fund budgeting, in order to achieve the target more effectively. According to the interview with an informant (Informant 1) that the researchers have found some data indicating the efforts of village government to enhance their capacity by using some strategies stated that:

"Actually in strengthening the capacity of village government to the implementation of village fund budgeting, we used an external organization to direct our program and give guidance in planning formulation" (informant 1).

Another informant gave his response about the strategy of village government to develop their capacity which can be elaborated as follows:

"In developing our knowledge and skill of the management of village budgeting program, we have coordinated with other institutions, such as university scholars and the counselors team who know well in designing village government work plan in the funding management" (Informant 2).

Based on the above responses from two informants it may be summarized that the strategy of village government in developing their capacity to manage the village fund used: (1) cooperation strategy with other organization, (2) horizontal coordination, and (3) involving some experts from the university. By doing that, the village government capacity may develop in designing the strategic planning in the implementation of village fund policy at Maros Regency.

\section{Empowerment Program}

The management of village fund budgeting seems very complex, because the village management has faced some determinations and conflict of interest in the implementation of 
village fund policy at the level of villages (Desa). Many actors and multi sectors have influenced the village government when they wanted to formulate the village fund planning. So then, the village head was always confused how to prioritize the program. Based on the guidelines for the use of village funds from the central government that the village fund used in infrastructure programs, empowerment, and economic development. In fact, the village government at Maros Regency neglected in the empowerment program for their community. Practically, the village fund at least $90 \%$ was allocated to infrastructure development. The problems may be occurred because there were some community agencies, for example the leader of the Village Community Empowerment Agency (LPMD) felt unsatisfied with the village head's program. So then, it leads to conflict of interest in the implementation of program. It can be proved from the results of interview stated that:

"In using the village fund budgeting, the programs which designed by the village heads and his colleagues tended to allocate on the infrastructure program, so then the empowerment programs to the community are neglected" (Informant 3)

Beside that, based on the result of interview from another informant gave his opinion as follows:

"As a matter of fact the village funding has not empowered community, even became just a source of trouble to the community" (Informant 4).

The responses of two informants above reveal that the empowerment programs which utilize village fund budget can be concluded that the empowerment of village government was less effective. This can be seen from the data in the field showing that the village government in managing the village fund only prioritizes the infrastructure program and they neglected the needs of community to lift up their knowledge and skill to be educated. Actually, the program should also be focused on giving the education and training for community so that they can live independently with their skills and knowledge. Actually, the village fund could also make the village government having more capacity in developing their skill and knowledge, but the facts shows that they do not have power to formulate the planning program in empowerment, because they perform by the rules of central government in allocating the village fund budget. It means that both village governments and society have been lack of strengthening their capacity. In this context, the main issues that the central government should change their policy in managing the village fund by giving to the village government to design the program based on the village society needs.

\section{Social Capital Development}

The theory of social capital used in this research is Ostrom theory (Ahn \& Ostrom 2008) explained about social capital which consists of; shared knowledge, understandings, norms, rules, and expectations. According to the result of interview with the informants confirmed that:

"The village fund program has not yet been strengthening the knowledge, understanding, norms, rules, and expectation". (Informant 5).

According to other informants has the same perception with the previously informant whom stated that: 
"The village fund has not been effective to develop the capacity or knowledge of community, because there are many village heads that has not followed the norms and expectation of community". (Informant 6).

Based on the response of informants, the social capital has not been achieved optimally, because the program implementation does not correlate with the social needs and the village government programs.

\section{Community Participation}

Based on the result of interview, the community participation in the implementation of village fund policy have not been developed systematically. This can be seen from some informant's response as follows:

"The community participations were not optimal because they felt dissatisfied about the village fund budgeting just to allocate on the infrastructure program" (Informant 8)

All of the informants' responses above implied that the communities' participations were insufficient to formulate the village fund program. The program actually should focus also on developing the community participation, so the program of village fund would have some supports from the society.

\section{The effectiveness of village fund policy implementation at Maros Regency}

In the implementation of village fund policy in the Maros Regency, actually there were some obstacle that should be overcome in order to achieve the successful of policy program. The result of interviews from the Head District of Maros stated that:

"Since the village fund has be delivering in to the village, Maros Regency Government and also each Head District at Maros Regency believed that the village government has capacity to carry out the programs as well as possible. But, in the fact showed that many programs of village government did not run effectively, such as to develop the village infrastructure and village community empowerment. The village government must be give some guidance and empowered through socialization of the village fund programs especially in the formulation program, implementation, and evaluation" (Head of Maros District/Camat, 2017).

According to the above statement, it can be stated that the implementation of village fund policy has still found some problems especially in planning program, implementation, and evaluation. Based on our observation showed that they still did not understand yet about how to design and formulate the activity programs which were funded by the village fund. This fact also confirmed by the Village Community Empowerment and Village Agency of Maros Regency stated that:

"The big problems that should be overcome in managing the village fund to get the program will achieve effectively is that the capacity of the village government. According to the result of our evaluation and monitoring revealed that they did not fully understand about how to design and formulate the program of village fund. It also got the negative effect to the progress report sometimes has not appropriate the planning program and the implementation". 
Based on the review document of village fund at the village government of Maros regency revealed that the financial liabilities report of village fund were still late to be submitted to the Community and Village Empowerment Office. Based on those interview, observation, and review document, it can be confirmed that the implementation of village fund policy at the Maros Regency has not been achieved effectively.

\section{Research Discussion}

The concept of strengthening the village government capacity through the utilization of village fund has more attention by some researchers recently. The village fund that has been programmed by the central government since 2015, aimed to enhance the capacity of community based on the needs of the society. Based on the theory of capacity building, it is stated that the program should enhance. First, the institution building which means that the village fund needs to build up the basic stock of functional institutions in the village government to implement the village fund policy. Second, the institutional strengthening development which is meant to strengthen and restructure the existing village institutions or organizations so that the goal in which management of programs of public investment' sourced by the village fund can have efficient use of existing funds. Third, capacity building relates to the human resource development. In this case, empowerment program such as the concentration on education, health, population development, and economic growth should be more paid attention more by the village government.

We identified that as a matter of fact in the strengthening the village government capacity at Maros Regency in the implementation of village fund policy needed four dimensions first; strategic thinking. It means that the village government should maintain the cooperation strategy with other community informal organization, make horizontal coordination with another village government, the societal groups, and the other stakeholders to make the village fund policy implementation more successfully. In this context, strategic thinking must be proved in the vision and mission programs in developing the capacity of village government.

It can be formulated as the design the strategic plan of village government at Maros Regency. Of course, the Government of Maros Regency should facilitate this efforts in order the village government found easily to design the strategic plan or the village government work plan. Second, empowerment. It becomes the best way to enhance the capacity of village government to make their capacity more highly in the village fund policy implementation. Empowerment include such as Government of Maros Regency should give education and training to the village government to develop the skill and knowledge of village government. Third, social capital development means that all components of community and village government should be empowered by village government.

The social capital weakness may reduce the success of village fund programs. In order to strengthen the capacity of village fund management, shared knowledge, understanding, norms, rules, and expectation are needed. Fourth, community participation is very necessary to develop 
the capacity of village government. Without any supporting or participation of community in the implementation of village fund policy, it may get negative effect or program will be failed. These functions include: (a) mobilization of financial resources especially village fund, (b) determination of broad policies, (c) allocation of resources, (d) planning of specific projects, (e) implementation of projects, and coordinating in the implementation of village fund projects. Relate to the role of the village head in design the programs, so then theory of empowerment argues that both a value of the goals of program that should be applied for community development and understanding the process and the results of efforts to exert control and influence over decisions that affect communities' life, organizational functioning, and the quality of community life (Perkins and Zimmerman, 1995; Rappaport, 1981; Zimmerman and Warschausky, 1998). Based on the research findings confirm that those four dimensions have benefits to develop the capacity of village government in the implementation of village fund policy. It means that the Government of Maros Regency should be considered that those theories are needed to be applied in order to strengthen the capacity of village government at Maros Regency.

\section{Conclusion}

Village fund policy has the advantages such as sustainability from social community development and village government performance improvement as the basis of autonomy, addresses all levels of capacity, overcome deeper issues for real change, and holistic-tailored to specific village or regency development. However, the goals of village fund to improve the capacity of village community and strengthening the capacity of village government especially at Maros Regency has not been implemented effectively. It can be proved by the research findings and data analyzed confirmed that there are some dimensions are still had to pay more attention in order to develop the capacity of village government such as; strategic thinking, empowerment, social capital development, and the community participation, because they have been still not optimally yet.

In achieving the effectiveness of the village fund policy, the role of central government and Government of Maros Regency suggest that to carry out the evaluation and monitoring of village fund more effectively. Because of the village government at Maros Regency have been still faced many obstacles and weakness in the implementation of village fund policy, so that empowerment of the village government should be done regularly by the Maros Regency Government. Meanwhile, the village government capacity and autonomy should be developed more optimally in order to achieve this village fund program more successfully especially at Maros Regency.

\section{References}

Ahn, Toh-Kyeong, \& Ostrom, E., (2008). Social Capital and Collective Action. In The Handbook of Social Capital, edited by Dario Castiglione, Jan Van Deth, and Guglielmo Wolleb, Oxford University Press, New York. 
Asni, F., Maryunani, Sasongko, Dwi Budi, M., (2013). The Management of the Village Fund Allocation as an Instrument towards Economic Independence Village (Case Studies in 2 villages in Siak Regency, Province Riau), IOSR Journal of Business and Management, Volume 10, Issue 4, pp. 1-9.

Boonperm, J., Haughton, J., Khandker, S.R., \& Rukumnuaykit, P., (2012). Appraising the Thailand Village Fund, Policy Research Working Paper, The World Bank Development Research Group Agriculture and Rural Development Team.

Horton, D., et al, (2003). Evaluating Capacity Development, Experiences from Research and Development Organizations around the World, International Service for National Agricultural Research (ISNAR), www.isnar.cgiar.org, Netherlands.

Perkins, D.D., \& Zimmerman, M.A., (1995). Empowerment Theory, Research, and Application, American Journal of Community Psychology, Volume 23, Issue 5, pp. 569-579.

Rappaport, J., (1981). The Power of Empowerment Language Social Policy, Vol.16, pp. 15-21.

Peraturan Menteri Pembangunan Desa Tertinggal dan Transmigrasi. 5 of 2015, Tentang Pedoman Pengelolaan Dana Desa, Kementerian PDT dan Transmigrasi, Jakarta.

Word Bank in Africa, The capacity building in Africa. In Freeman, K.M., (2010). Capacity Development Theory and Practice: Lessons learnt from CORD and KITWOBEE in Northern Uganda, Master of Arts degree in Development and Emergency Practice, Thesis, Oxford Brookes University 